\title{
The Influence of Perceived Human Resource Risk Factors on Financial Problems Faced by Overberg District Municipalities
}

\author{
Juan Pierre Bruwer, Jean-Pierre Rossouw \\ Cape Peninsula University of Technology Graduate Centre for management, South Africa \\ BruwerJP@cput.ac.za, jean-pierre@swellenmun.co.za
}

\begin{abstract}
Municipalities are at the forefront of South Africa's developmental agenda. To assist in the foregoing, the municipalities perform the primary task of service delivery - mandated by the Constitution of South Africa. The efficiency of the municipal service delivery function is depended on municipal funds, as derived from various sources. Apart from these funds, municipalities also receive funding through National and Provincial grant allocations, in addition. Notwithstanding the aforementioned most South African municipalities are experiencing financial problems which may adversely affect their relevant service delivery tasks. A possible contributor to the financial problems of South African municipalities is that of human resources (HR) risk factors. For this study, the emphasis was placed on testing whether perceived HR risk factors had any influence on the financial problems experienced in Overberg District Municipalities. Empirical research was conducted through the means of collecting quantitative primary data from 106 respondents, all of whom had to adhere to relevant delineation criteria. Stemming from the results, it was found that perceived HR risk factors did not have any statistically significant influence on the financial problems experienced in Overberg District Municipalities.
\end{abstract}

Keywords: Human resource risk factors; Financial Problems; Overberg District; Municipalities; South Africa.

\section{Introduction}

The term "municipality" is formally defined in the National Municipal Structures Act No. 177 of 1998, and the South African Constitution, as a body that should be established by every provincial government, with the main intent to provide for the monitoring and support of local government in a province; to promote the development of local government capacity to perform their functions and manage their own affairs (South Africa, 1998). Essentially, municipalities should assist the national government with the rendering of service delivery provincially and locally. Particularly, according to the South African Constitution (South Africa, 1996) the foregoing is done through providing assistance with the democratic and accountable government for local communities, ensuring the provision of basic municipal services ${ }^{1}$ to communities in a sustainable manner, promoting social and economic development, promoting safe and healthy environments, and encouraging the involvement of communities and community organizations in the matters of local government.

Notwithstanding the above South African municipalities are divided into three categories, namely: Category A) metropolitan municipalities (municipalities that have exclusive municipal executive- and legislative authority in their areas of operation); Category B); Local municipalities (municipalities that share municipal executive- and legislative authority in its areas of operation with a district municipality); and Category C). District municipalities (municipalities that have municipal executive- and legislative authority in areas of operation that may have more than one municipality) (South Africa, 1996) during the course of 2016, the most recent count of municipalities revealed that South Africa had 257 municipalities which comprised eight metropolitan municipalities, 44 district municipalities and 205 local municipalities (South Africa, 2016). The number of municipalities is justified by the continued growth of local economies, infrastructure and increased basic services in relevant communities (Western Cape Provincial Government, 2006). In order for municipalities to perform their relevant tasks, they need funding. Funding is generally obtained from three distinct sources. According to Local Government Action (2018) municipalities primarily raise funding by

${ }^{1}$ Basic municipal services pertain to those services that are necessary to ensure an acceptable and reasonable quality of life and which, if not provided, would endanger public health or safety or the environment (South Africa, 2003). 
means of three methods: 1) billing citizens who own property such as land, houses and businesses relevant rates based on the value of their property, 2) charging tariffs for services rendered.

To communities such as access to and provision of water, access to and provision of electricity, refuse removal and the use of municipal facilities, and 3) funding transfers from national and provincial government. To assist in the proper management of these funds and by securing a sound and sustainable management of the fiscal and financial affairs of municipalities, the National Municipal Finance Management Act (MFMA), Act No. 56 of 2003 was introduced. In terms of Section 62 (c) (i) of the MFMA, the Accounting Officer must take all reasonable steps to ensure (South Africa, 2003): "That the municipality has and maintains effective, efficient and transparent systems of financial and risk management and internal control" the MFMA further states that a municipal manager is regarded as the "Accounting Officer" and/or "Head of the Municipal Administration". Hence, clear tangent planes emerge that municipal managers have a lot of responsibility in relation to the financial sustainability of their respective municipalities. To assist the municipal manager in mitigating risks which may adversely affect the financial sustainability of his/her municipality, it is imperative that effective risk management processes should be deployed in municipalities. For the sake of clarity, a "risk" can be viewed as an uncertain event which may have an adverse influence on the overall attainment of business objectives (Smit, 2012). Hence, the inference can be made that $23.3 \%$ of respondents perceived their respective municipalities to go "beyond the call of duty" when compared to the expectations of a local municipality.

Based on previous research studies (Tchankova, 2002; Bruwer et al., 2013; Bruwer et al., 2018) risks in general, can be demarcated into four categories namely: 1) strategic risks, 2) compliance risks, 3) operational risks, and 4) reporting risks. In turn, a risk management process can be defined as "a process, effected by an entity's board of directors, management and other personnel, applied in strategy setting and across the enterprise, designed to identify potential events that may affect the entity, and manage risk to be within its risk appetite, and to provide reasonable assurance regarding the achievement of entity objectives" (COSO, 2004). This view is supported by the 2016 Overberg District Annual Report where it was found that due to skill and funding constraints, Overberg District Municipalities ${ }^{2}$ might not have sound risk management initiatives in place to mitigate and manage key organizational risks (ODM, 2016). Taking into account that the primary task (service delivery) of municipalities is generally to be executed by human resources, it is highly probable that perceived HR risk factors may contribute to possible financial problems experienced in South African municipalities, particularly Overberg District Municipalities. For the remainder of this paper, discussions take place under the following headings below: 1) literature review, 2) research design and methodology, 3) results and discussion, and 4) conclusion.

\section{Literature Review}

Under this section, the relevant discussion takes place under the following two sub-headings: 1) HR risk factors and 2) financial problems faced by South African municipalities.

HR Risk Factors: The primary tasks performed by municipalities are generally performed by human resources. When taking into account the municipal manager's responsibility for sound financial administration, among other responsibilities, it is highly probable that HR risks may adversely affect the financial sustainability of municipalities. HR risks are often spurred on by HR risk factors which are, in turn, can be described as uncertain events or factors which may have an adverse influence on the overall attainment of business objectives (Smit, 2012). Using the most recent revised Risk Management Policy of the Swellendam Local Municipality as a foundation (Swellendam Municipality, 2015), six critical HR risk factors have been identified in Overberg District Municipalities (see Figure 1). For the sake of clarity, each of these HR risk factors is elaborated on below (Menze, 2006; Van Vuuren, 2014; Amo, 2018; Randenberg, 2017; Drake International, 2018; Vesterin, 2018): Therefore, using the above as a basis, the average municipality

2 The Overberg District Municipalities comprise four local municipalities, namely: Theewaterskloof Municipality Over strand Municipality, Cape Agulhas Municipality and Swellendam Municipality (ODM, 2016). 
where respondents managed employed between 251 and 400 employees on a full-time basis that was responsible for the delivery of basic services to the local communities. Regardless of the statistics, it should be noted that all four municipalities are actually classified as local municipalities. In order to better understand the demographical profile of respondents, they were asked to indicate their highest qualification.

Figure 1: Critical HR Risk Factors in Overberg District Municipalities

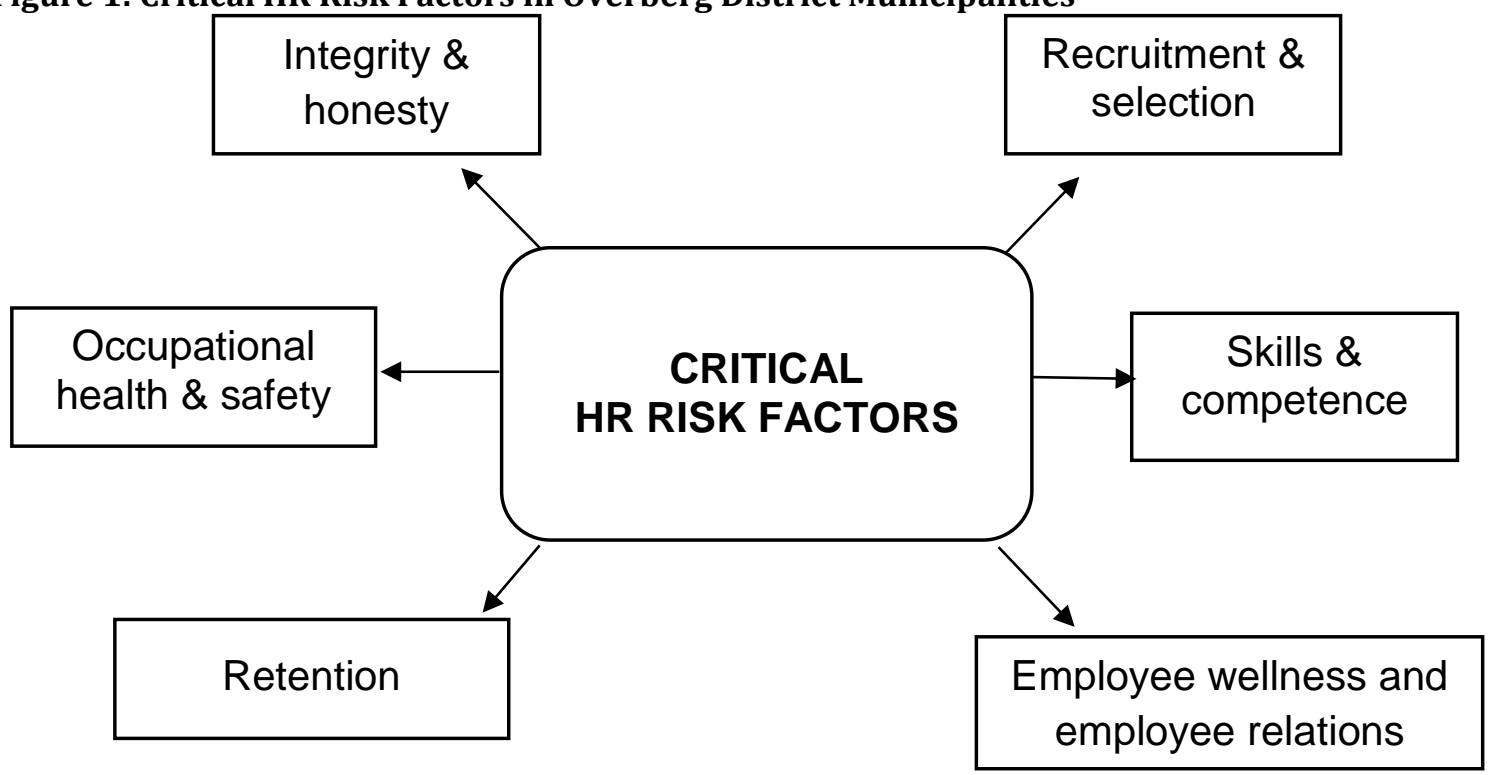

(Adapted from: Swellendam Municipality, 2015)

- Integrity and Honesty: Integrity and honesty are key morals in any organisation as they are imperative to systems, structures and overall leadership. An organisation's approaches and principles on business morals, whistleblowing, and human rights direct its workers and partners with respect on how it completes its business activities and what is anticipated from them.

- Recruitment and Selection: Appointing the ideal employees are critical to any organisation's operations. Employees should be efficient, competent and effective with the main intent to perform their job descriptions too, in turn, help achieve their organisations' primary objectives.

- Skills and Competence: Skills and competence refer to the extent to which employees can execute their job descriptions with adequate knowledge and training. Through the proper execution of their job descriptions, employees can not only help an organisation achieve its objectives but also allow them to be promoted. Through organisations' continuous professional development of their employees, a return on investment will become more evident.

- Employee Wellness and Employee Relations: Employee wellness is a non-negotiable in any organisation as employees should be healthy enough to perform their respective tasks (physical, emotional and/or spiritual). The negligence of employee wellness can result in lower levels of efficiency, extended absence and high staff turnovers. To assist in this regard, sound employee relations are recommended where organisations make an effort to build trustworthy relationships with employees.

- Occupational Health and Safety: In many industries, occupational health is heavily legislated and organisations should comply with relevant policies and procedures. All employees should be reasonably safeguarded from related dangers and risks (e.g. fires, blasts, synthetic risks or other such perils that present a quick danger to employees' lives). 
Financial Problems Faced by South African Municipalities: As previously mentioned, municipalities achieve their constitutional mandate by using funds as received from three avenues. Unfortunately, research shows that despite increases in funding responsibilities, many South African municipalities are undergoing financial problems (Kitchen, 2002). These high debt figures place the importance of addressing any contributing factors to the possible financial problems experienced by South African municipalities into context. A total of $8.7 \%$ had a postgraduate qualification, $30.1 \%$ had a bachelor's degree, $34.0 \%$ had a diploma, $14.6 \%$ had a higher certificate and $12.7 \%$ had matric. This view is supported by the $2016 / 2017$ MFMA Consolidated General Report where it was found that the financial health of municipalities shows a continuing decline in finances which, in turn, put these entities under increasing pressure to provide services (Auditor General, 2018).

In the same report, possible contributing factors to the financial problems of South African municipalities include the inability to collect outstanding debt, lack of financial management skills and the inability to pay creditors. According to the National Treasury's Media Statement on local government's revenue and expenditure for the fourth quarter of the 2017/18 financial year: "Aggregate municipal consumer debts amounted to R143.2 billion (compared to R139.2 billion reported in the third quarter) as at 30 June 2018 (2018)" it further states that a total amount of R1.3 billion has been written off as bad debt. The quarterly report also states.

\section{Research Design and Methodology}

This study was exploratory in nature and fell within the positivistic research paradigm. In quintessence, survey research was conducted with the main intent to obtain primary quantitative data from respondents. It needs to be acknowledged that not all the outstanding debt of R143.2 billion is realistically collectable as these amounts are inclusive of debt older than 90 days (historic debt that has accumulated over an extended period), interest on arrears and other recoveries" (National Treasury: 2018). Previous studies show that risk management systems deployed in South African municipalities might not be effective in their approach. Taking into consideration the foregoing, this study was also quantitative in nature and constituted survey research. Questionnaires were disseminated to respondents with the main intent to obtain their perceptions on relevant phenomena. The questionnaire used consist mostly of multiple choice questions and five-point Likert-scale questions $(1$ = very important, 2 = fairly important, $3=$ important, $4=$ slightly important, $5=$ not important). The Overberg District Municipalities employ approximately 280 employees at supervisor-, manager- and director levels. The targeted population of this study included these 280 employees (both female staff members and male staff members) in Overberg District Municipalities. All respondents had to:

- Be employed by one of the Overberg district municipalities;

- Be employed at supervisor/senior management level;

- Be exposed to the risk management processes of municipalities;

This study was subject to financial constraints (no formal budget was allocated to conduct this study) and time constraints (data had to be collected in a matter of two months' time). Moreover, the limitation of this study was that it solely focused on Overberg District Municipalities. It should, however, be noted that Overberg District Municipalities provide service delivery to approximately 260000 South African citizens representing an estimated $0.47 \%$ of the South African population (Indexmundi, 2018).

\section{Analysis of Results and Discussion}

In order to better understand the individual municipalities where respondents were based (part of Overberg District Municipalities), respondents were asked to describe their respective municipalities. First respondents were asked how many employees their municipalities employ on a full-time basis. A total of $2.9 \%$ indicated " $101-250$ employees", $62.7 \%$ indicated " $251-400$ employees", $17.5 \%$ indicated " $401-550$ employees" and 17.5\% indicated "more than 550 employees". Respondents were also asked to describe the type of municipality they managed. A total of $76.7 \%$ described their municipalities as a local municipality while $23.3 \%$ described their municipalities as district municipalities. In layperson terms, more than threequarters of Overberg District Municipalities were described by respondents to be local municipalities, 
responsible for service delivery. Furthermore, when asked how many years respondents have managed, $34.0 \%$ indicated "more than 15 years", 21.4\% indicated "between 11 and 15 years", 31.1\% indicated "between 6 and 10 years" and 13.6\% indicated "between 0 and 5 years".

Hence, on average, the average respondent had a tertiary education with at least 6 years' experience as a manager within one of the Overberg District Municipalities in relation to the posed research hypotheses respondents were asked whether their respective municipality experienced financial problems. A total of $54.4 \%$ responded "Yes" while $45.6 \%$ responded "No". To better understand where these financial problems stemmed from, respondents were asked to provide possible reasons. A total of $45.63 \%$ agreed that is was caused to slow paying debtors, $81.55 \%$ agreed that it was caused by overspending, $84.47 \%$ agreed that it was caused by irregularities, and $59.22 \%$ agreed it was caused by the lack of skilled human resources. Thus, using the above as a foundation, it appears that, Overberg District Municipalities experienced financial problems due to an array of probable reasons.

It should, however, be noted that the severity of the financial problems experienced by these municipalities was not asked and hence it may be that the financial problems experienced by Overberg District Municipalities were not necessarily severe. When taking into account that a lack of skilled human resources was identified by respondents as a possible reason for financial problems experienced in Overberg District Municipalities, respondents were asked to indicate the importance of identifying, assessing and treating perceived HR risk factors through mean of a five-point Likert-scale ( 1 = very important, 2 = fairly important, 3 = important, 4 = slightly important, 5 = not at all important). A summary of the results is shown in Table 1 .

Table 1: Importance of Identifying, Assessing and Treating Risks Related to Perceived HR Risk Factors

\begin{tabular}{|c|c|c|c|c|c|c|}
\hline HR Risk Factor & $\begin{array}{l}\text { Very } \\
\text { important }\end{array}$ & $\begin{array}{l}\text { Fairly } \\
\text { important }\end{array}$ & Important & $\begin{array}{l}\text { Slightly } \\
\text { important }\end{array}$ & $\begin{array}{l}\text { Not at all } \\
\text { important }\end{array}$ & Mean \\
\hline Integrity and honesty & $69.9 \%$ & $18.4 \%$ & $9.7 \%$ & $1.9 \%$ & - & 1.44 \\
\hline Skills and competence & $55.3 \%$ & $30.1 \%$ & $9.7 \%$ & $3.9 \%$ & $1.0 \%$ & 1.65 \\
\hline $\begin{array}{l}\text { Recruitment and } \\
\text { selection }\end{array}$ & $49.5 \%$ & $35.9 \%$ & $11.7 \%$ & $1.9 \%$ & $1.0 \%$ & 1.69 \\
\hline $\begin{array}{l}\text { Occupational health } \\
\text { and safety }\end{array}$ & $52.4 \%$ & $28.2 \%$ & $14.6 \%$ & $3.9 \%$ & $1.0 \%$ & 1.73 \\
\hline Employee wellness & $35.0 \%$ & $40.8 \%$ & $18.4 \%$ & $3.9 \%$ & $1.9 \%$ & 1.97 \\
\hline Employee relations & $29.1 \%$ & $43.7 \%$ & $20.4 \%$ & $3.9 \%$ & $2.9 \%$ & 2.08 \\
\hline Retention & $30.1 \%$ & $37.9 \%$ & $25.2 \%$ & $3.9 \%$ & $2.9 \%$ & 2.12 \\
\hline
\end{tabular}

From the statistics in Table 1, the inference can be made that respondents regarded the overall importance of identifying, assessing and treating of perceived HR risk factors as between "very important" (lowest mean score of 1.44) and "important" (highest mean score of 1.12). The top five HR risk factors identified were that of "integrity and honesty", "skills and competence", "recruitment and selection", "occupational health and safety" and "employee wellness". Notwithstanding the foregoing, it is interesting to note that although the perceived HR risk factor of "skills and competence" was regarded to be between "very important" and "fairly important, $55.22 \%$ of respondents indicated that this risk factor is to blame for financial problems evident in Overberg District Municipalities.

Reverting to the statistics in Table 1, two inferences can be made: 1) perceived HR risk factors may not be properly managed by management, and/or 2) management may not be properly authorised to appoint competent and skilled employees. Stemming from the above, and in order to better understand whether HR risk factors contributed to the financial problems of Overberg District Municipalities, inferential statistics were performed. To measure the independent variable of perceived HR risk factors, seven items were reduced to a single factor called $H R R F$ through principal axis factoring was used (see Table 2). This was made 
possible ${ }^{3}$ through a calculated Cronbach Alpha value of 0.932 and a KMO value of 0.855 . All individual values for the seven variables were averaged in order to get to average scores for the factor HRFF (as supported by Figure 1).

Table 2: Summary of Principal Axis Factoring for Factor HRRF

\begin{tabular}{llll}
\hline Item & Component matrix & Cronbach Alpha & KMO value \\
\hline Integrity and honesty & 0.871 & & \\
Recruitment and selection & 0.845 & & \\
Skills and competence & 0.878 & 0.932 & 0.855 \\
Employee wellness & 0.887 & & \\
Employee relations & 0.885 & & \\
Retention & 0.749 & & \\
Occupational health and safety & 0.807 & & \\
\hline
\end{tabular}

In order to measure whether $H R R F$ contributed to financial problems evident in Overberg District Municipalities financial problems, the Lambda Measure of Association test was performed. This test indicates as to whether an independent variable will have a statistically significant influence on a dependent variable, including the strength of such influence (Johnson \& Reynolds, 2011). A summary of the results is shown in Table 3.

Table 3: Summary of the Lambda Measure of Association Test Performed

\begin{tabular}{llll}
\hline Independent variable & Dependent variable & Lambda value $(\lambda)$ & Significance \\
\hline HRRF & Financial problems & 0.213 & 0.127 \\
\hline
\end{tabular}

Stemming from the results in Table 3, it becomes apparent that the factor $H R R F$ does not have any statistically significant influence on financial problems experienced in Overberg District Municipalities. Otherwise stated, when Overberg District Municipalities experienced financial problems, it was not caused by $H R R F$.

\section{Conclusion}

According to academic literature, South African municipalities are responsible for performing service delivery in national-, provincial- and local dispensations. When taking into account that service delivery is generally performed by employees, as well as the fact that South African municipalities are experiencing financial problems, it is disconcerting to note that perceived HR risk factors may adversely affect the financial sustainability of these entities. After testing whether perceived HR risk factors contributed towards the financial problems evident in Overberg District Municipalities the results allowed for the rejection of the formulated hypothesis. It should, however, be noted that though perceived HR risk factors were not found to contribute towards the financial problems experienced by Overberg District Municipalities, these risk factors may contribute to the financial problems experienced by other South African municipalities.

Avenues for Further Research: From the research conducted suggested avenues for further research include, but is not limited to: The contribution of other risk factors to the financial problems faced by Overberg District Municipalities. The contribution of HR risk factors to the financial problems faced by other South African municipalities.

\section{References}

Amo, T. (2018). The Negative Effects of a Lack of Training in the Workplace.

Auditor General. (2018). 2016/2017 MFMA Consolidated General Report on the Local Government Audit Outcomes.

\footnotetext{
${ }^{3}$ In order for a factor to be recognized as a legitimate factor, items should have a Cronbach Alpha of at least 0.700 and a KMO value of at least 0.600 .
} 
Bruwer, J. P., Masama, B., Mgidi, A., Myezo, M., Nqayi, P., Nzuza, N., Phangwa, M., Sibanyoni, S. \& Va, N. (2013). The need for a customized risk management framework for small enterprises. Southern African Accounting Association: Conference Proceedings.

Bruwer, J., Siwangaza, L. \& Smit, Y. (2018). Loss Control and Loss Control Strategies in SMMEs Operating in a Developing Country: A Literature Review. Expert Journal of Business and Management, 6(1), 1-11.

COSO. (2004). Enterprise risk management - integrated framework, Executive summary.

Drake international. (2018). Poor employee relations.

Indexmundi. (2018). South Africa.

Johnson, J. B. \& Reynolds, H. T. (2011). Political Science Research Methods 7th edition. SAGE Publications, London.

Kitchen, H. (2002). Canadian municipalities: Fiscal trends and sustainability. Canadian Tax Journal / Revue Fiscale Canadienne, 50(1), 156-80.

Local Government Action. (2018). South Africa.

Menze, M. (2006). The impact of stress on productivity of employees at the education training and development practices: Sector education and training authority. Unpublished Manuscript (Dissertation), University of Pretoria: Pretoria.

ODM. (2016). 2014/2015 Draft annual report. Published on 26 January 2016.

National Treasury. (2018). Media Statement: Local government revenue and expenditure: Fourth Quarter Local Government Section 71 Report. Published on 23 August 2018.

Randenberg, D. (2017). The Effects of a Failed Recruitment \& Selection System.

Smit, Y. (2012). A structured approach to risk management for South African SMEs. Unpublished Manuscript (Thesis), Cape Peninsula University of Technology: Cape Town.

South Africa. (1996). The Constitution of the Republic of South Africa. Pretoria: Government Printer.

South Africa. (2003). Municipal Finance Management Act, Act No. 56 of 2003. Government Gazette, Pretoria: Government Printer.

South Africa. (1998). The Municipal Structures Act, Act No. 117 of 1998. Pretoria: Government Printer.

South Africa. (2016). Local government.

Swellendam Municipality. (2015). Revised risk management policy.

Tchankova, L. (2002). Risk identification - basic stage in risk management. Environmental Management and Health, 13(3), 290-297.

Van Vuuren, L. (2014). Ethics Risk Handbook. 5th ed. Pretoria: The Ethics Institute.

Vesterinen, A. (2018). Occupational Safety: Why is it so important?

Western Cape Provincial Government. (2006). Micro-economic Development Strategy Synthesis Report. 